\title{
A Sagrada Inveja: \\ reflexões sobre emoções e interações competitivas entre trabalhadores fabris
}

Beatriz Rodrigues Kanaan*

\section{Resumo}

As reflexões trazidas neste texto fazem parte da minha tese de doutorado, na qual procuro compreender os dispositivos presentes na constituição de um tipo específico de trabalhador observado na Serra Gaúcha, importante polo industrial no Rio Grande do Sul. Aqui especificamente, coloco em foco um sentimento compartilhado entre trabalhadores(i)migrantes dessa região industrializada presente nas rivalizações e nas interações competitivas ao qual se referem como "inveja". As análises procuram evidenciar a capacidade micropolítica das emoções na recriação de um coletivo que emerge e se distingue cultural e economicamente em uma conjunção de fatores inseridos nos fluxos do mundo globalizado que aí ocorre de maneira particular e universal.

\section{Palavras-chave}

Antropologia. Emoções. Trabalho.

\begin{abstract}
The reflections shown in this text are part of my Doctoral thesis, in which I try to comprehend the devices present in the constitution of a specific type of worker observed in Serra Gaúcha, an important industrial park in Rio Grande do Sul. Here I specifically highlight a feeling shared amongst (im)migrant workers in this industrialized area, reflected in rivalries and competitive interactions which they referr to as 'envy'. The analysis will try to bring to light the micropolitical ability of emotions in the recreation of a collective which emerges and distinguishes itself culturally and economically in a array of factors inserted in the flows of our globalized world, which then happens in a particular and universal way.
\end{abstract}

\section{Keywords}

Anthropology. Emotions. Work.

\footnotetext{
* Beatriz Rodrigues Kanaan é professora do Centro de Ciências Humanas da Universidade de Caxias do Sul/RS. Doutorou-se em Antropologia Social pelo Programa de Pós Graduação da Universidade Federal do Rio Grande do Sul. Tem artigos e capítulos de livros publicados nas áreas de migrações e identidades étnicas. Atualmente suas principais áreas de interesse são migrações, trabalho e desenvolvimento econômico com ênfase na Antropologia das Emoções. Email: bekanaan@hotmail.com.
} 


\section{Introdução}

Este artigo coloca em evidência a presença de um sentimento compartilhado entre trabalhadores de uma região industrializada no nordeste do Rio Grande do Sul, nas rivalizações e nas interações competitivas, ao qual se referem como "inveja". As análises aqui presentes procuram evidenciar a capacidade micropolítica das emoções na recriação de um coletivo que emerge e se distingue cultural e economicamente em uma conjunção de fatores inseridos nos fluxos do mundo globalizado que aí ocorre de maneira particular e universal. ${ }^{1}$

A Serra Gaúcha, como a região nordeste do Rio Grande do Sul é conhecida, recentemente viveu um processo de industrialização, quando os pequenos municípios da região, até então com população predominantemente de descendentes de imigrantes italianos, com valores vinculados à terra, rapidamente se transformaram em modernos centros urbanos. As atividades comerciais desenvolvidas a partir da produção agrícola das colônias de imigração italiana - pequenas propriedades autossustentáveis - proporcionaram uma base sólida para a modernização da economia regional. Impulsionada por políticas econômicas nacionais, a cidade de Caxias do Sul concentrou importantes unidades industriais, principalmente no setor metalmecânico, constituindo juntamente com os municípios vizinhos um importante polo industrial.

A demanda de mão de obra gerada pelo crescimento da economia da região criou canais de migração por onde se deslocaram muitos trabalhadores de outros lugares do estado do Rio Grande do Sul. Inicialmente, a cidade de Caxias do Sul foi o principal polo de atração dessa emigração. Porém, logo outros municípios vizinhos também buscaram, através de iniciativas públicas e privadas, incentivar a implementação de fábricas.

Esse foi o caso da cidade de Farroupilha - recorte geográfico deste estudo - onde, em 1971, empresários e administradores públicos farroupilhenses

\footnotetext{
1 As reflexões neste texto fazem parte da minha tese de doutorado, na qual procuro compreender os dispositivos presentes na constituição de um tipo específico de trabalhador observado na Serra Gaúcha, no Rio Grande do Sul. A região, colonizada inicialmente por agricultores imigrantes provenientes da península itálica no final do século XIX, transformouse, em meados de 1970, em importante polo industrial. A partir de então, passou a atrair numerosa mão de obra entre trabalhadores de outras regiões do estado, reconfigurando as relações sociais em novo cenário.
} 
alinharam-se à dinamização da economia que viam acontecer em Caxias do Sul, tomando providências no sentido de incentivar a industrialização do município. Entre 1970 e 1995, segundo dados fornecidos pela Câmara de Indústria e Comércio de Farroupilha, a população passou de 20 mil para 55 mil habitantes. Hoje, estimativas do IBGE apontam uma população de 70 mil habitantes e seus índices socioeconômicos são comparáveis à situação de localidades de países desenvolvidos. Segundo o PNUD (Programa das Nações Unidas para o Desenvolvimento), o IDH na cidade é $0,844^{2}$, a expectativa de vida é de 74,1 anos, o analfabetismo é de $4,37 \%$ e a mortalidade infantil refere 12,89 por mil nascimentos.

Os descendentes de imigrantes italianos alicerçados na situação econômica de sua elite empresarial utilizam-se da ideia de anterioridade e pertencimento a uma origem comum para, na condição de estabelecidos, se dirigirem aos recentemente chegados como pessoas 'de fora', os outsiders. Configuram-se assim relações de poder muito similares à paradigmática de Winston Parva de Norbert Elias (2000), em que os recém-chegados são vistos como pessoas desprovidas das virtudes compartilhadas entre os descendentes de imigrantes. A vida centralizada em torno do trabalho e de atitudes que visem à poupança, a distância do lazer e do ócio e a paixão em competir são comportamentos tidos como "italianos" e que estariam ausentes nos novos migrantes.

Nas ações dos recém-chegados dirigidas à realização do projeto da migração - ou seja, mudar para 'melhorar de vida', - observa-se uma maior ou menor adesão ao ethos econômico local que explica a prosperidade e particulariza o modo de vida na região. Os novos migrantes, chamados a se autoreconhecer e a referendar o amplo repertório de qualidades morais tido como de 'maior virtude', aos poucos passam a invisibilizar suas próprias atitudes; isto é, procuram não demonstrar os comportamentos e valores que balizavam as interações em suas cidades de origem e que, no ambiente atual, encontram-se relacionados a um estilo de vida em que o trabalho não ocupa a centralidade do cotidiano.

\footnotetext{
${ }^{2} \mathrm{O}$ Índice de Desenvolvimento Humano (IDH) é um dado utilizado pela Organização das Nações Unidas (ONU) para analisar a qualidade de vida, com base na taxa de escolaridade, na renda e no nível de saúde de uma determinada população. De acordo com dados divulgados em novembro de 2010 pela ONU, o Brasil apresenta IDH de 0,73, valor considerado alto, ocupando o $85^{\circ}$ lugar no ranking mundial.
} 
A constituição de um sujeito mobilizado a trabalhar está assentada em experiências pelas quais eles passam a incorporar capacidades de ação e propensões para pensar, sentir e emocionar-se nesse contexto. No processo de aprendizagem de uma nova moralidade, o papel das emoções assume um valor comunicativo inestimável, haja vista que, por meio das emoções imputadas nas novas experiências, os sujeitos serão ou não afetados e, assim, motivados a transformações.

Neste texto, portanto, analiso a presença da "inveja" visando entender de que maneira e em quais circunstâncias esse sentimento é acionado pelos trabalhadores no processo da maior ou menor adesão às novas práticas de trabalho.

As reflexões deste estudo estão baseadas na realização de uma pesquisa etnográfica em uma fábrica de calçados, ramo que absorve trabalhadores com pouca qualificação, que se colocou como porta de entrada aos trabalhadores recém-chegados e, por isso, local estratégico para, a partir dos estranhamentos iniciais ao modo de trabalho fabril, observar os processos de inserção ao trabalho e de construção de si mesmos enquanto "bons" trabalhadores. Inserida no cotidiano da fábrica, durante seis meses observei as dinâmicas vividas pelos trabalhadores. Também foram gravadas entrevistas dentro e fora da fábrica quando acompanhei trabalhadorasmães até a porta das creches ou escolas no fim do dia, dirigi-me até templos neopentecostais com trabalhadores-pastores, tomei chá com trabalhadorasdonas de casa, sentei-me à varanda com trabalhadores-casais e, muitas vezes, conheci os trabalhos que eles somam ao trabalho na fábrica. Também estive junto a esses trabalhadores durante um evento festivo que é por eles tido como o maior e mais significativo evento da cidade: a Gincana, uma festa que coloca em foco as experiências cotidianas do trabalho como um jogo no qual observei a presença de emoções que dramatizam e valorizam comportamentos e atitudes como a disciplinaridade, as hierarquizações, as iniciativas de trabalho e as rivalidades.

\section{0 "sistema daqui"}

As relações utilitaristas, individualistas, mediadas pelo dinheiro são estranhadas pelos recém-chegados e identificadas como o "sistema daqui". Esse tipo de interações são para eles interações regidas por interesses e, por isso, consideradas desprovidas de afetos, levando-os a se referirem que a 
vida em Farroupilha é "uma vida sem sentido", "vida sem graça", "sem colorido" e da qual eles se sentem alheios. Muitas vezes ouvi-os dizendo que "aqui não se vive, vai se levando". ${ }^{3}$

O novo modo de trabalhar, as interações monetarizadas, o disciplinamento cotidiano, a permanente vigilância e autocontrole, assim como as relações individualistas, entrelaçam-se a sensações de frieza, de falta de afeto, que eles comparam e contrastam com os encontros efusivos e vibrantes que viviam em suas cidades de origem, onde lhes eram fornecidos momentos de prazer.

A carência de sentimentos apontados pelos trabalhadores ao inseriremse na sociedade fabril em Farroupilha remete à tradição do pensamento sociológico que se desenvolve sobre a ideia de que o poder do indivíduo moderno está atrelado ao seu autocontrole. Movido pela definição e execução de seus objetivos, ele vive sob a égide de valores e contra impulsos e emoções que o distraiam (WEBER, 2004). Porém, segundo outros autores, todas as ações (e, na verdade, as próprias razões) estão carregadas de emoções (BARBALET, 2002). Não se deve esquecer que o próprio Weber assinalou a importância de uma motivação que viesse envolver os protestantes nas práticas econômicas capitalistas. ${ }^{4}$

Em outros momentos e situações, a ideia de carência de sentimentos é expressa como a presença de sentimentos que os recém-chegados consideram negativos. Inicialmente, observa-se a dupla referência em suas vivências, nas quais os trabalhadores operam simultaneamente com as moralidades trazidas de sua cidade de origem e as que se apresentam nas interações em Farroupilha.

\footnotetext{
${ }^{3}$ Entendo a expressão 'sem graça' no mesmo sentido de outras muito frequentes entre os trabalhadores de Farroupilha, como 'vida sem colorido' como uma falta de vibração, de envolvimento dos sujeitos nas suas práticas cotidianas.

${ }^{4}$ As diferentes representações a que esses sujeitos se referem em relação ao trabalho remetem
às ideias de Weber (2004), desenvolvidas por HOLANDA (1997) e DAMATTA (1979) para
pensarem as particularidades da nação brasileira, quando aponta os valores e comportamentos
presentes entre os primeiros protestantes e imprescindíveis à gênese do capitalismo. Haja
visto que os recém-chegados, de forma similar aos sujeitos pertencentes às sociedades pré-
capitalistas tradicionais, motivados a trabalhar menos do que a ganhar mais, estranham os
costumes dos "italianos" em Farroupilha pelas atitudes que coincidem com as atitudes do
homem detentor de um "espírito capitalista", como descrito por Weber (2004) - isto é, aquele
que soma ao dever de trabalhar um "rigoroso espírito de poupança, que calcula o ganho e
seu montante geral a um severo domínio de si e uma sobriedade que elevam de maneira
excepcional a produtividade." (WEBER, 2004, p.57).
} 


\begin{abstract}
"A vida aqui é um tanto amarga, todos só têm tesão por estarem se digladiando uns com os outros, isto aqui é uma guerra. Assim, quer ver? Tudo é um negócio, e tu passa o tempo todo tendo que pensar em como não ser passado pra trás. Tem uma maldade, sei lá... No início eu ficava louco, achava uma loucura, mas o pior é que a gente acaba se acostumando... E, pensando aqui contigo, vou te dizer, quando tu vê tá até fazendo igual, Deus me perdoe! E com um certo gosto, afinal a gente leva tanto que dar o troco tem que ser bom, né... Tô falando isto agora contigo, porque senão a coisa passa por mim já de modo natural, assim... tu entende?".

[Trabalhador do setor de corte da Compax, reside em Farroupilha desde 1984].
\end{abstract}

Os trabalhadores recém-chegados têm inicialmente fortes objeções morais em relação ao sentimento de inveja que baliza as práticas competitivas compartilhadas entre os moradores de Farroupilha e demonstram-se resistentes em deixar de lado as relações de solidariedade e de camaradagem. Eles referem que conquistar amizades, auxiliarem-se entre si, parecem-lhes ações mais prazerosas e saudáveis à vida. Por outro lado, observei os moradores mais antigos vivenciando essas mesmas interações, porém atribuindo-lhes um outro sentido. Eles manifestavam satisfação ao se envolverem em práticas de rivalidades e em emoções aí implícitas que referiam como "inveja". Querer adquirir o que o outro tem, não deixar que os outros lhe passem à frente - às vezes, mesmo se utilizando de atitudes não consideradas éticas por eles, - são motivo de regozijo.

Diante dessas controversas emocionalidades entre os trabalhadores, fui levada a refletir sobre o quanto os comportamentos econômicos, considerados não emocionais para uns, são experiências apaixonantes para outros. Evidencia-se não a presença ou a falta de emoções, mas formas culturalmente distintas de lidar com o controle emotivo, como diria Lutz (1990).

No processo de ressocialização dos recém-chegados, a aquisição de disposições tem um componente emocional que se revela no fato de que a adesão às práticas inicialmente conscientes e incompreensíveis passa ao âmbito do espontâneo, natural, com a participação do sentimento de prazer. Como explica Barbalet (2002), as reações emocionais aos acontecimentos incluem sentimentos que indicam se uma experiência é suscetível de conduzir ao prazer ou à dor, configurando, a partir daí, as prováveis disposições para a ação. As atitudes que inicialmente lhes pareciam sem 
sentido, "uma loucura", são apreendidas cognitivamente na justaposição de um sentimento de satisfação vivido na exposição a essas experiências. Nesse momento, em que o trabalhador dá o troco com certo gosto, ele remete à ideia de que o sujeito se torna social quando sente prazer em compartilhar (CASTORIADIS, 1982, p.358) ou, sob outra perspectiva, remete-o ao prazer em participar do jogo social local.

Entendo "jogo" no sentido dado por Bourdieu como a maneira pela qual os sujeitos inseridos se movem de forma a dinamizar e trazer aspectos a um determinado campo. Sob a perspectiva do jogo, Bourdieu vai desenvolver a noção de illusio; isto é, o envolvimento dos sujeitos no jogo. Algo como "estar no jogo, estar envolvido no jogo, levar o jogo a sério". A illusio é prender-se ao jogo por acreditar que vale a pena jogar, o que implica dar importância também ao jogo; admitir, portanto, que o jogo merece ser jogado e que os alvos engendrados no e pelo fato de jogar merecem ser perseguidos (BOURDIEU, 2005).

Illusio é, portanto, segundo o autor, aquilo que envolve os sujeitos por se apresentar a eles como algo interessante. Bourdieu pensa a illusio em oposição à ataraxia - ausência de paixão, ausência de ação. Illusio, nesse sentido, está muito próxima da experiência de envolvimento que tenho acionado para entender sob o viés do envolvimento emocional os recém-chegados no processo de inserção ao mundo fabril de Farroupilha. Quando os trabalhadores dizem que passaram a "achar graça" nas práticas compartilhadas, eles referem o conhecimento e o reconhecimento dos elementos que estão em jogo e o sentimento de que vale a pena jogar esse jogo. Aquilo que inicialmente lhes parecia desinteressante e ao qual eram indiferentes, de alguma forma passa a lhes afetar, a envolvê-los, a emocioná-los de tal modo que, aos poucos, esses jogos se fazem esquecer como jogos. A illusio é essa "relação encantada" com um jogo, como diria Bourdieu (2005, p.140), na qual os recém-chegados expostos ao meio vão ou não inserir-se.

Como lembra por seu lado Barbalet (2002), é um desafio demonstrar a centralidade da emoção nas operações não desviantes da interação social. Então, como evidenciar a emoção nessa coletividade extremamente marcada pela ordem fabril, onde aparentemente não há emoções? Foi ao encontrar um momento de exceção no cotidiano dos trabalhadores que pude esquadrinhar a gramática emocional presente nas suas interações. Um evento da ordem da excepcionalidade, a Gincana de Farroupilha, forneceu elementos para pensar de que forma os sujeitos manejam seus sentimentos 
ao constituírem um coletivo tido e visto como distinto dos grupos do entorno, devido a comportamentos direcionados ao trabalho árduo, à vida austera e ao afastamento do ócio e do lazer.

\section{0 "trabalho" é a Festa}

O entusiasmo coletivo que presenciei entre os moradores da cidade sempre tão direcionados à vida no trabalho deixou claro que aquele era um momento extraordinário. A Gincana é, para eles, uma festa, a qual comentam ser o momento em que a população de Farroupilha se "diverte trabalhando". Mas, não é por ser um evento extraordinário que a Gincana se organiza em oposição ao mundo da ordem cotidiana. Muito pelo contrário. A festa está constituída pelos próprios elementos que regem o dia-a-dia da comunidade, trazendo para a centralidade da ação crenças e desejos forjados no processo histórico recente de industrialização e urbanização da cidade.

O trabalho, a astúcia, a capacidade de empreender, valores caros à coletividade fabril farroupilhense, estão reafirmados na estrutura formal e na natureza competitiva do evento. Esses elementos em nada diferem das práticas cotidianas, salvo algumas inversões nos papéis dos participantes. Por exemplo, pude observar, em determinados contextos do evento, empresários agindo sob a autoridade de um operário. Durante uma das reuniões realizadas para a organização da Gincana, um gerente de produção disciplinadamente levantou o braço e pediu licença ao jovem que presidia o encontro - e que era seu subalterno na empresa - para se retirar antes que esta terminasse, justificando um compromisso.

As atitudes rotineiras do cotidiano, presentes no evento da Gincana, se justapõem à inegável vibração que emana das pessoas durante a festa. Eu, que já não me surpreendia com as interações pouco expansivas entre as pessoas, logo percebi, quando presenciei pela primeira vez a Gincana, que algo diferente estava acontecendo. Fiquei surpresa com a espontaneidade com que conversavam umas com as outras e também comigo, oferecendo-se a uma cumplicidade que até então eu não havia observado. Lembro que, ao

\footnotetext{
${ }^{5}$ A festa é aqui entendida no sentido durkheimiano, ou seja, momento em que ocorre a produção de um estado de "efervescência coletiva" entre os envolvidos, no qual vivem a superação das distâncias entre eles, assim como a transgressão das normas coletivas.
} 
tentar me informar sobre o que estava acontecendo, as pessoas me diziam em uníssono: “O que? Tu não és daqui?", "É a primeira vez?”, "Então te prepara! Vais ver a coisa mais linda que acontece em Farroupilha". E ainda: "É o nosso carnaval".

Não me deterei aqui nos detalhes etnográficos da Gincana, apenas vou ressaltar alguns pontos importantes para as reflexões propostas. A festa é um evento bienal que congrega grande parte da população da cidade, uma vez que, de alguma forma, todos são envolvidos, quer espontaneamente, quer pelo simples fato de permanecerem na cidade durante os dois dias do evento. Os moradores da cidade apontam diferentes origens para a Gincana; no entanto, a década de 70 é referida por todos como data de início dessa festa, o que incide com o contexto da industrialização. Inicialmente, era uma competição entre empresas da cidade e, após ter passado pela gestão pública da prefeitura, hoje é organizada por uma rádio da cidade.

Segundo um dos promotores da Gincana, a garantia da realização de mais uma edição da festa está na certeza de que todos os participantes estão em paridade de competitividade, caso contrário não "teria graça". Assegurada a equalidade mínima para a competição, em geral cinco equipes participam, estruturadas em verdadeira gestão empresarial, organizadas sob hierarquias de diretoria administrativa, diretoria artística, setor financeiro, ou seja, como me informa orgulhosamente o presidente de umas das equipes competidoras, "igual a qualquer grande empresa".

$\mathrm{Na}$ abertura do evento, as equipes se apresentam desfilando pela rua principal da cidade. Esse desfile ao estilo carnavalesco passou a integrar o evento mais recentemente, o que pode ser visto como uma contribuição dos novos migrantes na estrutura da festa. $\mathrm{O}$ desfile, de fato, muito se assemelha aos desfiles de escola de samba do carnaval do Rio de Janeiro, no qual os integrantes passam pela rua principal ao som de 'hinos', paródias de músicas bem conhecidas, vestindo figurinos e apresentando alegorias grandiosas que versam sobre o tema escolhido pela equipe. Imediatamente após o desfile, iniciam as tarefas a serem executadas devidamente pontuadas a cada uma delas conforme o desempenho das equipes.

Os participantes da Gincana contam muitas histórias sobre essa acirrada competitividade e as estratégias - às vezes nem tão éticas - que elaboraram para vencer os adversários. Uma dessas histórias foi contada por um integrante de equipe, gincaneiro há 20 anos.

“A tarefa exigida era a de apresentar à comissão organizadora da Gincana no domingo uma pessoa com o nome de Domingo. Isto foi 
fácil, alguém da equipe conhecia um senhor chamado Domingo, morador daqui do Primeiro de Maio. Foram alguns gincaneiros atrás do homem, ele era inclusive gente nossa, simpatizante da nossa equipe. Acertaram com ele. Eu mandei o pessoal de volta para que isolassem o homem em um hotel de Caxias, com tudo pago. Afinal, era sábado, e o homem deveria ser apresentado só no dia seguinte. O problema é que o seu Domingo não queria ir pra Caxias. Então, eu mandei que pelo menos ficássemos com os documentos dele. No dia seguinte, quando chegamos na casa dele, uma outra equipe, fazendo-se passar pela nossa, já havia levado o homem. Voltamos para o QG sem saber o que fazer. Até que lembrei que estávamos de posse dos documentos dele. Olhei em torno da mesa onde estavam vários integrantes da equipe a matutar como sairíamos dessa. Apontei para um deles e disse: 'Tu é o Domingo, vamos lá!'. Apresentamos um colega com os documentos do Domingo verdadeiro. Ninguém poderia contestar, os documentos eram legítimos!".

[Líder de equipe da Gincana, descendente de imigrantes italianos]

A satisfação com que contam histórias sobre essas tarefas competitivas que requerem o que denominam de 'estratégias criativas' para vencerem o adversário é evidente devido à excitação com que falam e gesticulam, ao sorriso estampado nos rostos e aos inúmeros exemplos que fornecem.

Quando terminam de narrar as trapaças" que inventam, ou que em geral sofrem, eu pergunto-lhes: " a atitude tomada pelos adversários é considerada lesiva por vocês e isto não consta como regra da Gincana, então por que não denunciam à organização?!". Eles, sem exceção, me respondiam - alguns parecendo ser tomados de surpresa com a minha observação:- "Mas é aí é que está a graça da coisa!".

O clímax da Gincana acontece no momento da revelação do vencedor, com a entrega do troféu. Segundo os gincaneiros, "só duas equipes terminam satisfeitas: a que ganha e a que pensava ficar em último lugar e não ficou". - "Eles sabem que a única coisa que irão receber é o troféu, sem dinheiro ou qualquer bem material", comenta o organizador do evento. A equipe vencedora não ganha premiação alguma além do troféu, o que evidencia que a rivalidade entre as equipes por si só motiva a competição. A disputa, portanto, se sustenta somente pela vontade que eles têm de levarem vantagens uns sobre os outros. O que torna a Gincana tão absorvente não é simplesmente a realização das tarefas, o trabalho, mas sim a rivalidade, o jogo da competitividade, de querer superar o outro, que em termos de 
tomar o que o outro tem é traduzido como inveja.

Dois responsáveis por uma das equipes, conversando comigo no QG, tentaram me explicar sobre a sensação de ganhar a Gincana.

“Ganhar dá uma sensação incrível. Uma coisa assim... não dá pra explicar! Mas o bom mesmo quando a gente ganha de aí poder tocar flauta nos outros. É assim que nem Grenal, ${ }^{6}$ onde o melhor de tudo é ver o outro perder".

[Gincaneiro, descendente de imigrantes italianos]

\section{Festa, competição e emoções}

Em um âmbito mais amplo, a referência sobre a acirrada rivalidade informa sobre a presença da competitividade em outros contextos, mesmo que esta se dê, sobretudo, no plano das competições esportivas. O que ressalto, neste caso, é a centralidade que esse sentimento ocupa nas interações cotidianas dos sujeitos e a valorização positiva que a justifica autorizando a prática.

A Gincana está evidenciada e categorizada como festa num recorte já dado pelos participantes; é uma "categoria nativa". Peirano (2001) alerta que a excepcionalidade de um evento é um significado que deve ser trazido pelo 'nativo' e cabe ao pesquisador a habilidade de detectar o quê e quais são os momentos especiais para os sujeitos daquela sociedade. Mas será que a festa se resume "à mera fruição, divertimento ou válvula de escape do diaadia? Será que festejar se opõe à responsabilidade e à consciência social do cotidiano?" (AMARAL, 1998, p.5). Minha tarefa aqui é refletir sobre esse momento extraordinário, extremamente vinculado à ordem do cotidiano, trazendo a dimensão emocional para o foco das análises.

Tomar a Gincana como um evento, por sua natureza de excepcionalidade, permite que se aproxime os momentos da festa à ideia de communitas desenvolvida por Turner (1974), na qual o autor observa a dinâmica social como um processo vital, como oposição e complementaridade num processo dialético com a estrutura do cotidiano. Enquanto a estrutura é segmentária e hierárquica, a antiestrutura ou o evento à margem, neste

\footnotetext{
${ }^{6}$ Clássico do futebol gaúcho de grande rivalidade, o qual disputam os dois mais importantes times da capital do estado: Grêmio e Internacional.
} 
caso a Gincana, apresenta-se homogênea e igualitária, transtornando as hierarquias - seus participantes se reconhecem juntos numa "multidão de pessoas que não estão lado a lado (e, acrescente-se, acima e abaixo), mas umas com as outras" (TURNER, 1974, p.154). Ou seja, a festa se apresenta como um dos momentos da vida coletiva que proporciona aos homens uma libertação da estrutura social, quando então entram em communitas apenas para retornarem à estrutura, revitalizados por tal experiência.

As reflexões sobre esses fenômenos coletivos de efervescência foram inicialmente trazidas pela sociologia de Durkheim (2003) como momentos propícios à consolidação das crenças e regras do grupo, proporcionando em seus membros o sentimento de si mesmo, a sensação de pertencimento do sujeito ao coletivo. A festa se desenvolve a partir do repertório cultural do grupo. Da Matta (1979) diz que a festa tem a função de reforçar e/ou negar o modo pelo qual a sociedade que a celebra se organiza, através de uma seleção feita pela vontade do próprio grupo entre elementos que devem estar presentes e elementos que devem ser excluídos do evento. $\mathrm{Na}$ festa vislumbra-se um meio pelo qual o grupo se reafirma periodicamente ao reafirmar regras de conduta que prescrevem como o homem deve se comportar em relação ao sagrado, no sentido trazido por Hubert e Mauss (2005), de tudo aquilo que para os membros do grupo qualifica a sua sociedade. A festa assume, desta forma, um caráter simbólico, no qual, a partir de um fundo comum de crenças, a comunidade se "oferece em espetáculo" (MERIOT,1999, p.9). Ou ainda, como observa Geertz diante da briga de galos, é uma "história que eles contam a eles próprios sobre eles mesmos" (GEERTZ, 1989).

A partir da leitura de Tambiah (1996), penso que na festa os participantes experimentam intensamente uma performance que utiliza vários meios de comunicação, inclusive as emoções que nesse contexto passam a adquirir sentidos e valores, inferidos e criados pelos atores durante a experiência performática. Nesse sentido, observo, no desenrolar da Gincana, a pedagogia cognitiva/experiencial que informa aos neófitos sobre habilidades constituintes do meio fabril, como os saberes da gestão empresarial e das práticas do empreendedorismo, assim como a pedagogia emocional/ experiencial alinhando sentimentos às práticas fabris valorizadas pela coletividade. A Gincana é esse momento "bom para pensar e para viver", como diria Tambiah (1996), uma vez que nessas conformações performativas os gincaneiros se divertem competindo, rivalizando e se emocionando, validando e valorizando o sentimento e a prática da inveja entre eles. 


\title{
"Sagrada Inveja"
}

Poder-se-ia pensar que as emoções suscitadas na festa são vividas em oposição às emoções vividas no dia-a-dia, como uma permissividade da antiestrutura. No entanto, o que se pode notar é que a competitividade, as rivalizações e o sentimento de inveja encontram-se presentes nas relações cotidianas envolvendo várias e distintas circunstâncias. Como afirma Peirano (2001), "vivemos sistemas rituais complexos, interligados, sucessivos e vinculados, atualizando cosmologias e sendo por elas orientados" (p.28). Portanto, o que se observa no fragmento da festa é parte constituída e constituinte desse contexto em desenvolvimento econômico. Como relata um trabalhador recém-chegado em Farroupilha,

\begin{abstract}
“(...) A gente começa a trabalhar, vai crescendo... Todos nós temos ambição. A gente, por exemplo, vê o vizinho fazendo melhorias, uma cerca nova, e quer aquilo pra si também. Quando a gente pega a cultura do italiano de trabalhar e de cada vez querer ter mais, a gente acaba se dando tão bem quanto os gringos".

[Trabalhador da indústria, mora em Farroupilha desde 1980].
\end{abstract}

O comentário do trabalhador aponta que nesse contexto a possibilidade concreta de ascensão econômica é fator importante no estímulo à adesão a novos comportamentos. Assim ele se vê impulsionado a trabalhar mais, para obter mais, obter mais relacionado ao que o outro tem. Essa emulação social, como uma cópia do outro, no entanto, muitas vezes vai além; e eles agem de forma a se afastarem das condutas tradicionais e aprovadas nas suas cidades de origem. As denominadas 'estratégias criativas', observadas na Gincana, que tanto lhes proporcionam prazer, não deixam de ser 'trapaças', 'mentiras', realizadas no sentido não só de vencer, mas de destruir o adversário, as quais também se encontram presentes nas interações cotidianas. Ao prazer de vencer, de possuir o que o outro possui, acrescentam ações para superar o outro, muitas vezes destruindo-o. Uma trabalhadora na fábrica, com uma expressão de alegria me conta como passou na frente de uma outra pretendente ao emprego dela.

“Sabe como eu consegui este emprego? Eu trabalhava de agente de saúde e não aguentava mais o serviço lá. Aí, um dia, por acaso ouvi duas moças na sala de espera do posto falando que tinha esta vaga. A mais velha estava no posto justamente pra pegar atestado 
porque tinha faltado o emprego pra dar jeito no currículo que precisava pra trazer aqui pra fábrica. Eu ouvi e me deu uma coisa, inventei que tinha uma visita domiciliar e saí correndo do posto. Passei em casa peguei meu currículo e estou aqui! Ahah! Ela nem imagina que eu passei ela pra trás! (diz a trabalhadora com um ar de satisfação indescritível no rosto)".

[Trabalhadora da indústria, mora em Farroupilha desde 2005]

Outros, sem estarem alinhados às práticas competitivas, procuram esconder qualquer evidência que provoque a inveja. Percebo, em muitos dos novos imigrantes, um sentimento de resignação. É o caso de um exfuncionário da fábrica que realizou alguns cursos e abriu a "muito custo" uma fabriqueta de calçados na garagem. Queixa-se, com ar resignado, dos outros, os "empresários maiores, os italianos". Diz que eles chamam mãode-obra de fora e depois reclamam da falta de qualificação dos operários que aqui chegam. Mas, segundo ele, se chegar com muita qualificação "tu vais é ficar de fora: Inveja! Tu não podes parecer melhor que eles. A gente tem é que ralar mesmo". Um dia o microempresário me mostrou vários certificados de cursos de especialização na sua área profissional, que não estão pendurados na parede, como se costuma ver em outros estabelecimentos em outros lugares. Ele explica: "Não posso nem querer mostrar, vai ser pior pra mim".

Um provérbio muito repetido entre os moradores de Farroupilha dá o tom exato desse jogo, no qual não basta vencer, tem que se assegurar do fracasso do outro.

Diz o "gringo" ao fazer negócios:

Bom pra ti, ruim pra mim, não tem negócio.

Bom pra ti, bom pra mim, não tem negócio.

Ruim pra ti, bom pra mim, negócio fechado".

O mecanismo explicitado pelo ditado popular deixa claro que o que eles entendem por inveja não é senão o mesmo que a literatura existente considera. Ou seja, esse é um sentimento que se pauta na comparação com o 'outro' e que não aparece somente diante da frustração pela realização do outro, mas na alegria pelo mal do outro. Entretanto, se a inveja é um sentimento que pode ser encontrado em diversos contextos históricos e culturais, o foco aqui é o exame de seus contornos nesse contexto etnográfico 
específico, à luz da moral ocidental cristã no qual se encontra inserida.

Observo que esse sentimento não se dirige a alguém em particular. Os trabalhadores, quando comentam a inveja, dizem: “Tu já viste como o povo daqui é invejoso?"; “... é gente muito invejosa, esta daqui!”. Percebo que esse sentimento não é atribuído a uma pessoa ou coisa específica. Não é o vizinho do lado ou o colega de trabalho que é invejoso, é o "povo daqui", ou seja, a inveja aparece despersonalizada, sem localização determinada. O que leva a pensar que a inveja, nesse contexto, está a circular entre os sujeitos e as coisas (AHMED, 2004); o sujeito é simplesmente um ponto nodal nessa economia emocional.

Isto fica ainda mais evidente quando o prefeito orgulhosamente afirma que, se não fosse esse comportamento "não seríamos o que somos hoje, a nossa inveja é o motor do progresso". Ele reafirma a ideia de que a inveja circula, ao invés de ser atribuída à pessoa, ela aparece entre elas, mobilizando-as e alinhando-as em torno de uma dinâmica de ação que está direcionada ao desenvolvimento econômico. Dessa forma, a inveja faz coisas - ela é "motor" - envolvendo os sujeitos sem residir neles.

O sentimento muitas vezes é referido como a "sagrada inveja"7 que, compartilhado sob o estatuto do "sagrado" evidencia que este é vivido de maneira suprapessoal; ou seja, a inveja está presente entre os trabalhadores em nome da própria distintividade da coletividade.

Porém, como lembra Campbell (2001), é pouco provável que considerações utilitaristas como, por exemplo, de que é a inveja que traz progresso, derrubem os argumentos morais que os recém-chegados vinculam ao sentimento da inveja. Esse sentimento, muitas vezes, choca e angustia os novos migrantes que se sentem constrangidos a interagir desse modo que eles avaliam como agressivo, antissocial e individualista e que passam a relacionar ao estilo de vida dos descendentes de imigrantes italianos.

As produções históricas e literárias sobre a região informam que os membros da 'italianidade' já viviam comportamentos similares e por isso sugiro aqui tomar a inveja no contexto atual como uma reatualização de

\footnotetext{
${ }^{7}$ A versão virtuosa que eleva a inveja ao domínio do Sagrado sugere a retirada desse sentimento do nível humano, em que é considerada um « vício », e sua manifestação tenderia a provocar rompimentos e desordem. Essa concepção de que essa emoção está no nível do sagrado parece justificar a sua articulação com as práticas mundanas.
} 
comportamentos muito valorizados entre os primeiros imigrantes. Santin (1990), resgatando a vida agrária dos pioneiros, refere-se à predominância de projetos individuais e à rivalidade entre os colonos dizendo que "em muitos casos nada mais foi que fazer de tudo para que o outro não progredisse" (SANTIN, 1990, p.460). Costa (1998), ao lado dos muitos atributos dos descendentes de imigrantes italianos na Serra Gaúcha, que ressaltam a religiosidade, o apego à família e o impulso ao trabalho, soma outras virtudes nem sempre tão difundidas para definir os "italianos". O autor, um intelectual orgânico, admite, por exemplo:

"Com toda a franqueza que nossos métodos nem sempre são os
mais honestos, ou melhor, que a gente, para vencer na vida, tem
que ser "furbo" (astuto): descobrir o furo da lei, sonegar, sempre
que possível, pedir concordata na hora certa, "ciavar i baùchi"
(enganar os tolos), que podem ser nossos familiares ou sócios"
(COSTA,1998, p.20).

Logo a seguir, o autor complementa: "Além de 'furbo', deve ser trabalhador e econômico (idem)".

Percebo que os trabalhadores recém-chegados vivenciam insatisfações pela ausência de relações de solidariedade que tinham em suas cidades de origem e por não entenderem a "graça" que pode ter a paixão suscitada nas interações competitivas. $\mathrm{O}$ deslocamento das emoções passa por um intercâmbio entre as noções do corpo pessoal-individual e o corpo social coletivo e simbólico e, como observa Scheper-Hughes (1992), toma a forma de emoção de corpo aflito, expressado neste caso na epidêmica "tristeza". As queixas do "triste", de forma similar ao "nervoso" de Duarte (1993), são uma expressão que emerge embutida nas tensões vividas nas relações de desigualdade e dominação e na transformação da vida (DUARTE, 1993), como uma forma de resistência ao "sistema" dessa coletividade.

Assim é que a cidade de Farroupilha, além de ser tida e vista como uma cidade próspera e moderna, também agrega o predicado de triste. A Secretaria da Educação recentemente lançou um projeto no qual "as escolas devem ensinar canto, teatro e dança, para que o povo deixe de ser triste" [secretária Municipal da Educação em entrevista concedida em março de 2008]. Há uma história muito difundida entre os moradores da cidade sobre uma "famosa vidente" do centro do país que, certa vez, foi convidada para palestrar num município da Serra Gaúcha. Essa pessoa, supostamente com "poderes paranormais", dirigindo-se pela rodovia rumo à cidade 
onde iria palestrar, subitamente, teve um mal-estar e exclamou aos seus acompanhantes: - "Que horror! Por onde estamos passando? Sinto algo sombrio!". Foi-lhe dito que estavam passando pela cidade de Farroupilha. Ela explicou, então, a partir do mal-estar que sentia, que aquela era uma cidade muito triste, pois, ali pairava uma "nuvem negra de maus fluidos". $\mathrm{O}$ que interessa nessa análise não é a veracidade da história, mas a recorrência do relato que de certa forma expressa os dilemas dos trabalhadores expondo suas tensões emocionais e os pontos de fuga por meio dos quais estão a forjar suas subjetividades.

\section{Considerações finais}

É possível observar entre os trabalhadores recém-chegados à cidade de Farroupilha que alguns logo se inserem no jogo social de rivalidades. Outros, no entanto, não conseguem romper com os padrões de comportamento trazidos de seus locais de origem, expressando dificuldades ao relacionaremse frente a tanta competitividade. Há trabalhadores que chegam mesmo a voltar para suas cidades de origem, desistindo do projeto da migração.

À medida que um componente emocional alinha essas interações ao sentimento de prazer, a adesão às práticas, inicialmente conscientes e incompreensíveis, passa para o âmbito do espontâneo. Com isso, observo que a Gincana age como uma aprendizagem emocional, por meio da qual os trabalhadores passam, aos poucos, a dar sentido ao sentimento de inveja, ao serem inseridos nos significados e nos prazeres das rivalizações nessa coletividade fabril.

A Gincana informa aos trabalhadores acerca da pedagogia emocional / experiencial do lugar; alinhando assim sentimentos às práticas valorizadas pela coletividade, uma vez que nas conformações performativas da festa, os gincaneiros se divertem competindo, rivalizando e se emocionando. Dessa forma, há valorização do sentimento e da prática da "inveja" entre eles.

Nos dilemas vividos pelos recém-chegados prevalece a valoração moral positiva da "inveja", incentivando a competição e promovendo o sucesso dos projetos profissionais individuais que se alinham ao projeto mais amplo dessa coletividade. Emerge, então, uma região que se distingue cultural e economicamente, em uma conjunção de fatores inseridos nos fluxos do mundo globalizado que aí ocorre de maneira particular e universal. 


\section{Referências}

ABU-LUGHOD, Lila; LUTZ, Catherine

(1990). Language and the politics of emotion. Cambridge, Cambridge University of California Press. p. 1-23.

AHMED, Sarah.

(2004). Affective economies. Social Text 79, 22 (2), p.117-139.

AMARAL, Rita.

(1998). Os sentidos da festa. Travessia. Revista do Migrante. Centro de Estudos Migratórios, São Paulo.

BALEN, Ítalo.

(1981). Os Pesos e as Medidas. Porto Alegre, EST/ UCS.

BARBALET, Jack.

(2002). Emotions and sociology. 0xford, Blackwell Publishing.

BATTISTEL, Arlindo; COSTA, Rovílio.

(1983). Assim vivem os italianos. Porto Alegre, EST / Caxias do Sul, EDUCS.

COSTA, Rovílio.; DE BONI, Luis Alberto.

(1998). Nós os gringos. In: M. Maestri (Org.); Nós os ítalogaúchos. Porto Alegre, EDUFRGS.

COELH0, Maria Claudia; REZENDE, Claudia Barcellos (Orgs.).

(2011). Cultura e sentimentos: ensaios em antropologia das emoções. Rio de Janeiro, Contracapa / FAPERJ.

CAMPBELL, Colin.

(2001). A ética romântica e o espírito do consumismo moderno. Rio de Janeiro, Rocco.

DAMATA, Roberto.

(1979). Carnavais, Malandros e Heróis. Rio de Janeiro, Zahar.

DE BONI, Luís Alberto; COSTA, Rovílio.

(1984). Os italianos do Rio Grande do Sul. Porto Alegre, EST / EDUCS.
DAM0, Arlei Sander.

(2007). Do dom à profissão. A formação de futebolistas no Brasil e na França. São Paulo, Aderaldo \& Rothschild / ANPOCS.

(2006). Pessoa e coisa: o duplo estatuto dos jogadores de futebol profissional. In: $30^{\circ}$ Encontro Anual da Anpocs. Caxambu, Anpocs. Disponivel em : http://www.anpocs. com/index.php/papers-30-encontro/st-6/ st03-5/3549-adamo-pessoa/file Acessado em: janeiro /2012

DURÃ0, Susana.

(2009). 0 espectáculo das emoções. AfroReggae, uma ONG brasileira em acção. Paper apresentado no(a) $33^{\circ}$ Encontro anual da Anpocs, Gt 38: Subjectividade e Emoções. Caxambu, Minas Gerais.

DURKHEIM, Émile.

(2003). As formas elementares da vida religiosa. São Paulo, Martins Fontes.

ELIAS, Norbert.

(2000). Os Estabelecidos e os Outsiders. Rio de Janeiro, Jorge Zahar.

GEERTZ, Clifford.

(1989). A Interpretação das Culturas. Rio de Janeiro, LTC.

HERÉDIA, Vânia Merlotti.

(1997). Processo de industrialização da zona colonial italiana. Caxias do Sul, EDUCS.

HUBERT, Henry; MAUSS, Marcel.

(2005). Sobre o sacrifício. São Paulo, Cosac \& Naify.

KANAAN, Beatriz Rodrigues.

(2008). Imigrações contemporâneas $e$ italianidade: um estudo sobre jogos identitários na região industrializada de Farroupilha - RS. Dissertação de Mestrado em Antropologia Social apresentado ao Programa de Pós-graduação em Antropologia Social (PPGAS), Uniersidade Federal do Rio Grande do Sul (UFRGS). 
KLEIN, Melanie.

(1984). Inveja e gratidão: um estudo das fontes inconscientes. Rio de Janeiro, Imago.

LEAVITT, John

(1996). Meaning and feeling in the anthropology of emotions. In: American Ethnologist 23, pp. 514-539.

MANFROI, Olívio.

(1975). A Colonização Italiana no Rio Grande do Sul. Porto Alegre, IEL / Grafesul.

MANFRED F.R. Kets de Vries

(1996). A Inveja, grande esquecida dos fatores de motivação em gestão. In: 0 indivíduo $e$ a organização: dimensões esquecidas. São Paulo, Atlas.

PEIRANO, Mariza

(2003). Rituais ontem e hoje. Rio de Janeiro, Jorge Zahar.

REZENDE, Claudia Barcellos; COELH0, Maria Claudia.

(2010). Antropologia das Emoções. Rio de Janeiro, FGV.

SOUZA, Jessé de. (0rg.).

(1999). O Malandro e o protestante. A tese weberiana e a singularidade cultural brasileira. Brasília, UnB.
SPINOZA, Baruch.

(s/d). Ética. Rio de Janeiro, Edições de Ouro.

TAMBIAH, Stanley.

(1996). Leveling crowds: ethnonationalist conflicts and colletive violence in south Asia. Berkeley, University of California Press.

TEIXEIRA, Sérgio Alves.

(1988). Os recados das festas. Rio de Janeiro, FUNARTE / Instituto Nacional do Folclore.

TOMÁS DE AQUINO, Santo.

(2004). Sobre o ensino; Os sete pecados capitais. 2. ed. São Paulo, Martins Fontes.

TURNER, Victor Witter.

(1974). 0 processo ritual: estrutura e antiestrutura. Petrópolis, Vozes.

WEBER, Max.

(2004). A ética protestante e o espírito capitalista. São Paulo, Companhia das Letras.

\section{Recebido em}

dezembro de 2016

\section{Aprovado em}

março de 2017 